\title{
Aplikasi Pupuk Mikotricho (Mikoriza-Trichoderma) dan Pupuk Sintetik pada Budidaya Cabai Merah
}

\author{
Application of Mikotricho (Mycorrhizae-Trichoderma) Fertilizer and Synthetic \\ Fertilizer on Cultivation of Red Pepper
}

\author{
Eny Rokhminarsi ${ }^{1 *}$, Darini Sri Utami ${ }^{1}$, dan Begananda ${ }^{1}$ \\ Diterima 08 Februari 2019/Disetujui 21 Oktober 2019
}

\begin{abstract}
The aim of the study was to determine the optimal dosage of mycotricho fertilizer and the reduction dosage of synthetic fertilizer for growth and yield of red pepper on marginal land. The study was conducted from March to September 2018 on the ultisol soil in Kaliori village, Kalibagor sub-district, Banyumas district. The experiment used a Randomized Completely Block Design with 3 replications. The first factor was the dose of mycotricho i.e without mycotricho, $10 \mathrm{~g}$ mycorrhizae $+10 \mathrm{~g}$ Trichoderma, and $20 \mathrm{~g}$ mycorrhizae $+20 \mathrm{~g}$ Trichoderma. The second factor was the reduction of recommended synthetic fertilizer dosage i.e 0\% (recommended dose $=S P-36480 \mathrm{~kg}$ $\mathrm{ha}^{-1}$ was converted to SP-27 $640 \mathrm{~kg} \mathrm{ha}^{-1}, \mathrm{ZA} 320 \mathrm{~kg} \mathrm{ha}^{-1}$, urea $240 \mathrm{~kg} \mathrm{ha}^{-1}, 320 \mathrm{~kg} \mathrm{ha} \mathrm{K}^{-1} \mathrm{KCl}$ ), reduction of $25 \%$ and $50 \%$. Data were analized with ANOVA and Duncan's multiple range test $5 \%$. The results showed (1) the application of mycotricho to $40 \mathrm{~g}(20 \mathrm{~g}$ mycorrhizae $+20 \mathrm{~g}$

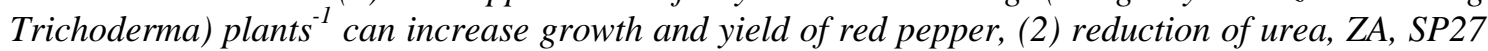
and $\mathrm{KCl}$ up to $25 \%$ of recommended dosage showed better growth and yield of red pepper than recommended dosages, (3) application of $40 \mathrm{~g}$ mycotricho $(20 \mathrm{~g}$ mycorrhizae $+20 \mathrm{~g}$ Trichoderma) with $25 \%$ reduction synthetic fertilizer gave growth to the optimal number of leaves, leaf area, and number of branches and increased yield of red pepper $\left(15.4 \mathrm{th} \mathrm{h}^{-1}\right)$ of $22.2 \%$ compared to without mycotricho at recommended doses (12.6 $\left.\mathrm{th}^{-1}\right)$. Application of $20 \mathrm{~g}$ mycotricho $(10 \mathrm{~g}$ mycorrhizae + $10 \mathrm{~g}$ Trichoderma) and 25\% reduction of synthetic fertilizer increased of yield $15.8 \%$ (14.6 $\left.\mathrm{th} \mathrm{h}^{-1}\right)$ compared to without mycotricho and the recommended dosage of synthetic fertilizer.
\end{abstract}

Keywords: biofertilizer, biopesticide, cultivation, vegetables

\begin{abstract}
ABSTRAK
Tujuan penelitian adalah menentukan dosis optimal pupuk mikotricho dan pengurangan dosis pupuk sintetis terhadap pertumbuhan dan hasil cabai merah di lahan marjinal. Penelitian dilaksanakan pada bulan Maret sampai September 2018. Penelitian merupakan percobaan lapang di desa Kaliori, Kecamatan Kalibagor, Kabupaten Banyumas, dengan jenis tanah ultisol menggunakan Rancangan Acak Kelompok Lengkap Teracak (RAKLT) dengan 3 ulangan. Faktor pertama perlakuan adalah dosis pupuk mikotricho yaitu tanpa pupuk mikotricho, dosis $10 \mathrm{~g}$ mikoriza $+10 \mathrm{~g}$ Trichoderma, $20 \mathrm{~g}$ mikoriza $+20 \mathrm{~g}$ Trichoderma. Faktor kedua adalah pengurangan dosis rekomendasi pupuk sintetis yaitu $0 \%$ (dosis rekomendasi $=$ SP-36 $480 \mathrm{~kg} \mathrm{ha}^{-1}$ dikonversi menjadi pupuk SP-27 $640 \mathrm{~kg} \mathrm{ha}^{-1}$, dan pupuk susulan berupa pupuk ZA $320 \mathrm{~kg} \mathrm{ha}^{-1}$, pupuk urea $240 \mathrm{~kg} \mathrm{ha}^{-1}$, pupuk $\mathrm{KCl} 320 \mathrm{~kg} \mathrm{ha}^{-1}$ ), pengurangan $25 \%$ dan 50\%. Analisis data menggunakan analisis ragam dan uji lanjut Duncan's Multiple Range Test 5\%. Hasil penelitian menunjukkan (1) pemberian pupuk hayati mikotricho hingga $40 \mathrm{~g}\left(20 \mathrm{~g}\right.$ mikoriza $+20 \mathrm{~g}$ Trichoderma) $\operatorname{tanaman}^{-1}$ dapat meningkatkan pertumbuhan dan hasil cabai merah, (2) pengurangan dosis pupuk sintetik urea, ZA, SP27 dan KCl hingga 25\% dari dosis rekomendasi menunjukkan pertumbuhan dan hasil cabai merah lebih baik dibandingkan dosis rekomendasi, (3) pemberian pupuk mikotricho dosis $40 \mathrm{~g}$ (20 g mikoriza $+20 \mathrm{~g}$
\end{abstract}

${ }^{1}$ Jurusan Agroteknologi, Fakultas Pertanian, Universitas Jenderal Soedirman, Purwokerto

Jl. Dr. Suparno Karangwangkal Purwokerto 53123, Jawa Tengah.

E-mail: enyrokhminarsi@gmail.com(*Penulis korespondensi) 
Trichoderma) dengan pengurangan $25 \%$ pupuk sintetik memberikan pertumbuhan jumlah daun, luas daun, dan jumlah cabang yang optimal serta peningkatan hasil cabai $\left(15.4 \mathrm{t} \mathrm{ha}^{-1)}\right.$ sebesar $22.2 \%$ dibandingkan tanpa pupuk mikotricho dengan dosis rekomendasi $\left(12.6 \mathrm{t} \mathrm{ha}^{-1}\right)$. Pemberian pupuk mikotricho $20 \mathrm{~g}$ (10 g mikoriza dan $10 \mathrm{~g}$ Trichoderma) dan pengurangan dosis pupuk sintetik $25 \%$, peningkatan hasil $15.8 \%\left(14.6 \mathrm{t} \mathrm{ha}^{-1}\right)$ dibandingkan tanpa pupuk mikotricho dan dosis rekomendasi pupuk sintetik.

Kata kunci: biopestisida, budidaya, cabai merah, pupuk hayati

\section{PENDAHULUAN}

Cabai merah (Capsicum annuum L.) merupakan salah satu jenis sayuran yang cukup penting di Indonesia, baik sebagai komoditas yang dikonsumsi di dalam negeri maupun sebagai komoditas ekspor.Sebagai sayuran, cabai merah selain memiliki nilai gizi yang cukup tinggi, juga mempunyai nilai ekonomi tinggi (Harpenas dan Dermawan, 2011)

Kebutuhan cabai tahun 2016 diproyeksikan akan naik $0.23 \%$ dari tahun sebelumnya menjadi sebesar 483296 ton, kemudian, pada tahun 2017 diperkirakan akan meningkat lagi $1.21 \%$ dari nilai proyeksi tahun 2016 menjadi sebesar 489137 ton (Yanuarti dan Afsari, 2016). Kebutuhan terebut menekankan para petani untuk menghasilkan cabai dalam jumlah yang tinggi, agar dapat memenuhi kebutuhan seluruh masyarakat. Untuk memenuhi kebutuhan konsumen, produksi cabai dapat dilakukan diantaranya melalui perluasan areal tanam ke lahan marjinal seperti Ultisol. Permasalahannya adalah bahwa tanah Ultisol mempunyai kemasaman tanah rendah, $\mathrm{pH}$ rata-rata $<4.5$, kejenuhan Al tinggi, miskin kandungan hara makro terutama Fosfor (P), Kalium (K), Kalsium (Ca), dan Magnesium (Mg) serta kandungan bahan organik rendah (Prasetyo dan Suriadikarta, 2006). Pada umumnya, petani memberikan pupuk sintetis (anorganik) sebagai upaya untuk meningkatkan kesuburan tanahnya, tetapi akibat penggunaan pupuk kimia pada lahan dapat merusak struktur tanah (tanah menjadi keras) (Suwardi dan Wijaya, 2013). Masalah lainnya dalam budidaya tanaman sayuran termasuk cabai merah, adalah penggunaan pestisida yang sangat intensif untuk mengendalikan hama dan penyakit. Berdasarkan survey di lapangan penggunaan pestisida tersebut dapat dilakukan 2 sampai 3 hari sekali ketika dijumpai hama atau patogen penyebab penyakit dengan serangan yang tinggi. Menurut Sari et al. (2016), sisi lain dari aplikasi pestisida yang mudah digunakan juga berdampak negatif terhadap petani, lingkungan, tanaman dan masyarakat sebagai konsumen produk pertanian.

Salah satu solusi untuk mengatasi permasalahan kondisi lahan marjinal dan budidaya tanaman cabai merah adalah melalui penerapan pupuk hayati Mikotricho yang mengandung mikroba berguna mikoriza dan Trichoderma sehingga dapat meningkatkan produksi dan mengurangi pemakaian pupuk sintetik. Hal ini karena cendawan mikoriza dapat membantu tersedianya unsur hara bagi tanaman, sedangkan Trichoderma spp. merupakan cendawan antagonis yang paling banyak digunakan untuk pengendalian patogen tular tanah. Sifat antagonis Trichoderma spp. dapat dimanfaatkan sebagai alternatif dalam pengendalian patogen yang bersifat ramah lingkungan (Dwiastuti et al., 2015), namun saat ini juga dimanfaatkan untuk memacu pertumbuhan tanaman (Ozbay et al., 2005). Cendawan Trichoderma spp. juga membantu tanaman menyerap unsur hara tertentu terutama fosfat (Poulton et al., 2011). Penelitian ini bertujuan menentukan dosis optimum pupuk Mikotricho dan pupuk sintetis yang optimal untuk pertumbuhan dan hasil tanaman cabai di lahan marjinal.

\section{BAHAN DAN METODE}

Penelitian berupa percobaan lapangan di desa Kaliori kecamatan Kalibagor kabupaten Banyumas selama 8 bulan dimulai Maret sampai September 2018. Bahan yang digunakan yaitu lahan marjinal dengan jenis ultisol, pupuk Mikotricho yaitu pupuk mikoriza-Trichoderma spesifik lokasi lahan marjinal (Rokhminarsi et al., 2011), kompos, pupuk urea, SP27, ZA, KCl, benih cabai 
varietas Dana, dan biopestisida Bio P60. Bio P60 merupakan biopestisida cair yang dapat menekan penyakit tanaman hingga 70-80\% yang disebabkan oleh cendawan, virus dan bakteri serta dapat menghasilkan hormon, antibiotik, beberapa enzim, dan stabil terhadap perubahan serta tidak berbahaya bagi manusia (http://www.unsoed.ac.id/id/node/922). Cara aplikasi dilakukan melalui perendaman benih, penyiraman pada bibit dan tanaman dengan interval 3-5 hari sekali.

Perlakuan yang dicoba terdiri atas 2 faktor yang dirancang dalam Rancangan Acak Kelompok Lengkap Teracak (RAKLT) dan diulang tiga kali. Faktor pertama adalah dosis pupuk Mikotricho, yang terdiri atas 3 level yaitu: tanpa pupuk mikotricho, $10 \mathrm{~g}$ mikoriza $+10 \mathrm{~g}$ Trichoderma, $20 \mathrm{~g}$ mikoriza $+20 \mathrm{~g}$ Trichoderma. Pupuk Mikotricho diberikan sekali bersamaan dengan penanaman bibit cabai. Faktor kedua adalahpengurangan dosis pupuk sintetik yang terdiri atas 3 level yaitu: kontrol (dosis rekomendasi), pengurangan 25\% dari rekomendasi, dan pengurangan $50 \%$ dari rekomendasi. Dosis rekomendasi yang digunakan untuk pemupukan cabai merah mengikuti Balai Pengkajian Teknologi Pertanian (2004), berupa pupuk dasar SP-36 $480 \mathrm{~kg} \mathrm{ha}^{-1}$ dikonversi menjadi pupuk SP-27 $640 \mathrm{~kg} \mathrm{ha}^{-1}$, dan pupuk susulan berupa pupuk ZA $320 \mathrm{~kg} \mathrm{ha}^{-1}$, pupuk Urea $240 \mathrm{~kg} \mathrm{ha}^{-1}$, pupuk KCl $320 \mathrm{~kg} \mathrm{ha}^{-1}$. Pupuk susulan diberikan 3 kali yaitu pada umur 1, 3 dan 5 minggu setelah tanaman. Dalam percobaan ini ukuran petak adalah $3 \mathrm{~m} \times 2 \mathrm{~m}$ dengan jarak tanam $40 \mathrm{~cm} \times 60 \mathrm{~cm}$ sehingga tiap petak percobaan terdapat 25 tanaman dengan jumlah tanaman sampel sebanyak 5 tanaman yang diambil di bagian tengah petak secara diagonal.

Variabel yang diamati dalam percobaan ini adalah persentase infeksi mikoriza (PIM), tinggi tanaman, jumlah daun, luas daun, jumlah cabang, bobot tajuk kering, bobot tanaman kering, jumlah buah, bobot buah tanaman $^{-1}$, dan hasil ha ${ }^{-1}$. Data hasil pengamatan dianalisis menggunakan analisis ragam (ANOVA) pada tingkat kesalahan 5\% dan apabila terdapat pengaruh nyata dilakukan uji lanjut dengan DMRT (Duncan's Multiple Range Test).

\section{HASIL DAN PEMBAHASAN}

Persentase infeksi mikoriza (PIM) dipengaruhi oleh pupuk mikotricho tetapi tidak dipengaruhi secara nyata oleh pengurangan pupuk sintetik (Tabel 1). Pemberian pupuk mikotricho dosis $10 \mathrm{~g}$ mikoriza $+10 \mathrm{~g}$ Trichoderma (20 g mikotricho) maupun $20 \mathrm{~g}$ mikoriza $+20 \mathrm{~g}$ Trichoderma $(40 \mathrm{~g}$ mikotricho) dapat meningkatkan PIM. Pada perlakuan tanpa pemberian pupuk mikotricho terjadi infeksi pada akar tanaman, hal ini menunjukkan bahwa terdapat mikoriza indigenous yang ada di tanah sebelum perlakuan. Hasil analisis tanah awal menunjukkan bahwa setiap $50 \mathrm{~g}$ tanah mengandung spora mikoriza sebanyak 85 spora. Spora indigenous ini yang menginfeksi perakaran tanaman cabai merah.

\section{Pengaruh Pupuk Mikotricho dan Pengurangan Pupuk Sintetik Terhadap Persentase Infeksi Mikoriza}

Pemberian pupuk Mikotricho pada
tanaman cabai merah secara nyata meningkatkan persentase infeksi mikoriza sebesar 4.25 sampai 4.8 kali dibandingkan dengan tanpa mikotricho (Tabel 1). Hal ini menunjukkan bahwa mikoriza yang diinokulasikan pada tanaman cabai dapat menginfeksi akar tanaman dengan baik. Menurut Sukmawaty et al. (2016), infeksi cendawan mikoriza arbuskula dipengaruhi oleh kepekaan inang terhadap infeksi, faktor iklim dan faktor tanah.

\section{Pengaruh Pupuk Mikotricho dan Pengurangan Pupuk Sintetik Terhadap Tinggi Tanaman Cabai}

Tinggi tanaman tidak dipengaruhi oleh pupuk mikotricho tetapi dipengaruhi secara nyata oleh pengurangan pupuk sintetik (Tabel 1). Pengurangan dosis pupuk sintetik sebesar 25\% dari rekomendasi menunjukkan tanaman nyata paling tinggi dibandingkan dengan kontrol (sesuai rekomendasi) maupun pengurangan $50 \%$. Tinggi tanaman pada pengurangan pupuk $25 \%$ diduga karena adanya mikoriza indigenous yang menginfeksi perakaran tanaman pada tanah percobaan, sehingga dapat membantu menyediakan unsur hara bagi tanaman khususnya P dan kebutuhan unsur hara bagi tanaman dapat terpenuhi. 
Pengurangan pupuk hingga 50\% menyebabkan tinggi tanaman menjadi nyata berkurang, hal tersebut diduga adanya pengurangan unsur hara sehingga mengurangi kebutuhan hara bagi tanaman cabai.

Menurut Faranso dan Susila (2015), ketersediaan hara $\mathrm{P}$ yang cukup selama masa pertumbuhan dan perkembangan tanaman dapat menyebabkan pemupukan $\mathrm{P}$ tidak berpengaruh terhadap pertumbuhan dan hasil tanaman. Menurut Pangaribuan et al. (2017), kombinasi pupuk organik cair $60 \%$ dengan dosis $\mathrm{N}, \mathrm{P}, \mathrm{K}$ rekomendasi memberikan pengaruh tinggi tanaman yang lebih baik daripada tanpa pupuk.
Pengaruh Pupuk Mikotricho Terhadap Jumlah Daun, Luas Daun dan Jumlah Cabang Tanaman Cabai

Pemberian dosis pupuk mikotricho dosis $20 \mathrm{~g}$ mikoriza $+20 \mathrm{~g}$ Trichoderma pada pengurangan pupuk sintetis $25 \%$ nyata meningkatkan jumlah daun, luas daun dan jumlah cabang dibandingkan dengan perlakuan lainnya (Tabel 1). Kandungan mikoriza dan Trichoderma pada pupuk mikotricho $20 \mathrm{~g}$ mikoriza $+20 \mathrm{~g}$ Trichoderma tersebut diduga berpengaruh positif terhadap penyerapan unsur-unsur hara termasuk nitrogen.

Tabel 1. Hasil analisis ragam pengaruh pupuk mikotricho dan pupuk sintetik terhadap pertumbuhan dan hasil cabai merah

\begin{tabular}{|c|c|c|c|c|c|c|c|c|c|c|}
\hline \multirow[b]{2}{*}{ Perlakuan } & \multicolumn{6}{|c|}{ Pertumbuhan } & \multicolumn{3}{|c|}{ Hasil } & \multirow[b]{2}{*}{$\begin{array}{l}\text { PI } \\
(\%)\end{array}$} \\
\hline & $\begin{array}{l}\mathrm{TT} \\
(\mathrm{cm})\end{array}$ & $\begin{array}{c}\text { JD } \\
\text { (helai) }\end{array}$ & $\begin{array}{l}\mathrm{LD} \\
\left(\mathrm{cm}^{2}\right)\end{array}$ & $\mathrm{JC}$ & BTK & $\begin{array}{c}\text { BTan. } \\
\text { K }\end{array}$ & JB & $\begin{array}{c}\mathrm{BB} \\
\tan ^{-1} \\
(\mathrm{~g})\end{array}$ & $\begin{array}{l}\text { BB } \\
\text { ha }^{-1}\end{array}$ & \\
\hline \multicolumn{11}{|c|}{ Pupuk Hayati Mikotricho (H) } \\
\hline $\mathrm{HO}$ & 53.7 & $88.9 \mathrm{~b}$ & $2337.5 \mathrm{~b}$ & $21.7 \mathrm{c}$ & 34.5 & 42.3 & 28.3 & $39.4 \mathrm{~b}$ & $11.3 \mathrm{~b}$ & $8.3 \mathrm{~b}$ \\
\hline $\mathrm{H} 1$ & 53.7 & $89.4 \mathrm{~b}$ & $2506.4 \mathrm{a}$ & $23.6 \mathrm{~b}$ & 32.0 & 37.8 & 29.1 & $46.3 \mathrm{a}$ & $13.7 \mathrm{a}$ & $35.3 \mathrm{a}$ \\
\hline $\mathrm{H} 2$ & 54.9 & $97.8 \mathrm{a}$ & $2761.2 \mathrm{a}$ & $25.9 \mathrm{a}$ & 30.1 & 33.7 & 30.1 & $49.0 \mathrm{a}$ & $14.1 \mathrm{a}$ & $40.0 \mathrm{a}$ \\
\hline $\begin{array}{l}\text { Uji F } \alpha \\
=5 \%\end{array}$ & $\begin{array}{l}\text { Tidak } \\
\text { nyata }\end{array}$ & Nyata & Nyata & Nyata & $\begin{array}{l}\text { Tidak } \\
\text { nyata }\end{array}$ & $\begin{array}{l}\text { Tidak } \\
\text { nyata }\end{array}$ & $\begin{array}{l}\text { Tidak } \\
\text { nyata }\end{array}$ & Nyata & Nyata & Nyata \\
\hline \multicolumn{11}{|c|}{ Pupuk Sintetik (A) } \\
\hline A0 & $55.3 \mathrm{~b}$ & $89.1 \mathrm{~b}$ & $2647.9 \mathrm{~b}$ & $24.0 \mathrm{~b}$ & 31.2 & 38.32 & 29.2 & $47.4 \mathrm{a}$ & 13.9 & 25.6 \\
\hline A1 & $58.2 \mathrm{a}$ & $108.2 \mathrm{a}$ & $3159.7 \mathrm{a}$ & $26.5 \mathrm{a}$ & 33.5 & 39.24 & 31.5 & $49.4 \mathrm{a}$ & 13.8 & 25.3 \\
\hline A2 & $48.9 \mathrm{c}$ & $78.2 \mathrm{c}$ & $1797.7 \mathrm{c}$ & $20.0 \mathrm{c}$ & 31.9 & 36.35 & 26.8 & $37.9 \mathrm{~b}$ & 11.6 & 32.8 \\
\hline $\begin{array}{l}\text { Uji F } \alpha \\
=5 \%\end{array}$ & Nyata & Nyata & Nyata & Nyata & $\begin{array}{l}\text { Tidak } \\
\text { nyata }\end{array}$ & $\begin{array}{l}\text { Tidak } \\
\text { nyata }\end{array}$ & $\begin{array}{l}\text { Tidak } \\
\text { nyata }\end{array}$ & Nyata & $\begin{array}{l}\text { Tidak } \\
\text { nyata }\end{array}$ & $\begin{array}{l}\text { Tidak } \\
\text { nyata }\end{array}$ \\
\hline \multicolumn{11}{|c|}{ Kombinasi Perlakuan Pupuk Hayati Mikotricho dan Pupuk Sintetik } \\
\hline H0A0 & 56.4 & 89.7 bc & $2750.2 \mathrm{c}$ & $23.1 \mathrm{c}$ & 37.9 & 47.6 & 30.0 & $46.0 \mathrm{~b}$ & $12.6 \mathrm{~b}$ & $10.0 \mathrm{~b}$ \\
\hline H0A1 & 54.9 & $96.2 \mathrm{~b}$ & $2376.9 \mathrm{~cd}$ & $21.1 \mathrm{~cd}$ & 33.7 & 41.4 & 28.7 & $38.5 \mathrm{~b}$ & $\begin{array}{c}11.3 \\
b c\end{array}$ & $6.7 \mathrm{~b}$ \\
\hline H0A2 & 49.9 & $80.9 \mathrm{c}$ & $1885.5 \mathrm{de}$ & $18.9 \mathrm{~d}$ & 31.8 & 38.0 & 26.1 & $34.1 \mathrm{~b}$ & $9.9 \mathrm{c}$ & $8.3 \mathrm{~b}$ \\
\hline H1A0 & 52.4 & $82.1 \mathrm{c}$ & $2492.8 \mathrm{c}$ & $21.5 \mathrm{~cd}$ & 29.2 & 38.3 & 27.9 & $47.8 \mathrm{~b}$ & $a^{14.6}$ & $33.3 \mathrm{a}$ \\
\hline H1A1 & 59.8 & $\begin{array}{c}110.4 \\
\mathrm{ab}\end{array}$ & $3294.1 \mathrm{~b}$ & $28.3 \mathrm{ab}$ & 29.9 & 33.9 & 32.7 & $52.8 \mathrm{a}$ & $14.6 \mathrm{a}$ & $29.3 \mathrm{a}$ \\
\hline H1A2 & 48.9 & $75.9 \mathrm{c}$ & $1732.4 \mathrm{e}$ & $20.9 \mathrm{~cd}$ & 36.8 & 41.2 & 26.6 & $38.3 \mathrm{~b}$ & $12.2 \mathrm{~b}$ & $43.3 \mathrm{a}$ \\
\hline $\mathrm{H} 2 \mathrm{~A} 0$ & 57.3 & $95.5 \mathrm{~b}$ & $2700.1 \mathrm{c}$ & $27.5 \mathrm{~b}$ & 26.4 & 29.0 & 29.8 & $48.7 \mathrm{a}$ & $14.4 \mathrm{a}$ & $33.3 \mathrm{a}$ \\
\hline $\mathrm{H} 2 \mathrm{~A} 1$ & 60.1 & $118.1 \mathrm{a}$ & $3808.3 \mathrm{a}$ & $30.1 \mathrm{a}$ & 36.8 & 42.4 & 33.1 & $57.0 \mathrm{a}$ & $15.4 \mathrm{a}$ & $40.0 \mathrm{a}$ \\
\hline $\mathrm{H} 2 \mathrm{~A} 2$ & 47.3 & $77.9 \mathrm{c}$ & $1775.4 \mathrm{e}$ & $20.3 \mathrm{~d}$ & 27.2 & 29.8 & 27.5 & $41.5 \mathrm{~b}$ & $12.6 \mathrm{~b}$ & $46.7 \mathrm{a}$ \\
\hline $\begin{array}{c}\text { Uji F } \alpha \\
=5 \%\end{array}$ & $\begin{array}{l}\text { Tidak } \\
\text { nyata }\end{array}$ & Nyata & Nyata & Nyata & $\begin{array}{l}\text { Tidak } \\
\text { nyata }\end{array}$ & $\begin{array}{l}\text { Tidak } \\
\text { nyata }\end{array}$ & $\begin{array}{l}\text { Tidak } \\
\text { nyata }\end{array}$ & Nyata & Nyata & Nyata \\
\hline
\end{tabular}

Keterangan: $\mathrm{TT}=$ Tinggitanaman $; \mathrm{JD}=$ Jumlah daun $; \mathrm{LD}=$ Luas daun $; \mathrm{JC}=\mathrm{Jumlah}$ Cabang ; $\mathrm{BTK}=$ Bobot Tajuk Kering ; BTan.K= Bobot Tanaman Kering ; $\mathrm{JB}=\mathrm{Jumlah}$ Buah ; $\mathrm{BB}=$ Bobot Buah ; PI= Persen Infeksi mikor. Angka yang diikuti dengan huruf yang berbeda pada kolom yang sama menunjukkan berbeda nyata. $\mathrm{H} 0=$ tanpa pupuk mikotricho, $\mathrm{H} 1=10 \mathrm{~g}$ pupuk mikoriza $+10 \mathrm{~g}$ Trichoderma, $\mathrm{H} 2=20 \mathrm{~g}$ pupuk mikoriza $+20 \mathrm{~g}$ Trichoderma, $\mathrm{A} 0=$ kontrol (dosis rekomendasi), $\mathrm{A} 1=$ pengurangan $25 \%$ dosis pupuk sintetik, A2 = pengurangan 50\% dosis pupuk sintetik. 
Unsur nitrogen berperan dalam pertumbuhan vegetatif tanaman termasuk jumlah dan luas daun serta jumlah cabang. Menurut Baskoro dan Purwoko (2010), meningkatnya jumlah daun berhubungan dengan tersedianya unsur nitrogen dalam media tumbuh, semakin banyak nitrogen tersedia di dalam tanah, pembentukan daun pun akan semakin banyak. Penambahan jumlah daun akan menambah luas daun total tanaman cabai. Pemberian Trichoderma dapat meningkatkan kandungan unsur hara, mampu memperbaiki struktur tanah, membuat agregat atau butiran tanah menjadi besar, mampu menahan air sehingga aerasi di dalamnya menjadi lancar dan dapat meningkatkan perkembangan akar (Charisma et al., 2012).

Pada Tabel 1 terlihat bahwa pemberian pupuk hayati mikotricho pada dosis $20 \mathrm{~g}$ mikoriza $+20 \mathrm{~g}$ Trichoderma dengan pengurangan dosis pupuk sintetik $25 \%$ nyata meningkatkan jumlah cabang sebesar $30.3 \%$ dibandingkan tanpa pupuk hayati mikotricho dengan dosis rekomendasi pupuk sintetik. Cabang merupakan tempat tumbuhnya bunga dan produksi tanaman cabai dimana buah cabai menempel pada cabang tersebut. Sedangkan pada variabel jumlah daun nyata peningkatannya sebesar $31.7 \%$ dan pada luas daun nyata sebesar $38.5 \%$ dibandingkan tanpa pupuk mikotricho dengan dosis rekomendasi pupuk sintetik.

Penambahan jumlah daun dan luas daun tanaman cabai akan meningkatkan hasil fotosintat yang digunakan sebagai simpanan di dalam buah cabai merah. Menurut Cruz et al. (2004), cendawan mikoriza menginfeksi sistem perakaran tanaman inang, kemudian memproduksi jaringan hifa eksternal yang tumbuh secara ekspansif dan menembus lapisan sub soil sehingga meningkatkan kapasitas akar dalam penyerapan hara dan air. Mikoriza juga dapat membantu di dalam siklus unsur hara, yaitu dengan memfasilitasi penyerapan hara dalam tanah sehingga dapat meningkatkan pertumbuhan tanaman (Nurhalimah et al., 2014), termasuk jumlah cabang. Selain pengaruh dari mikoriza, menurut Naemah et al. (2003), Trichoderma dapat menstimulasi perkecambahan spora cendawan mikoriza, artinya adanya Trichoderma di rizosfer memberikan efek positip dalam pembentukan mikoriza yang kemudian secara bersinergi atau berinteraksi akan mempengaruhi pertumbuhan tanaman selanjutnya.

\section{Pengaruh Pupuk Mikotricho terhadap Bobot Buah per Tanaman dan Hasil per Ha}

Bobot buah cabai tiap tanaman dan tiap hektar (Tabel 1) tidak terdapat interaksi antara pupuk mikotricho dan pengurangan dosis pupuk sintetik, namun terdapat kombinasi yang nyata. Pada Tabel 1 terlihat bahwa pengaruh mandiri pupuk mikotricho dosis $20 \mathrm{~g}$ (10 g mikoriza $+10 \mathrm{~g}$ Trichoderma) maupun 40 g (20 g mikoriza +20 g Trichoderma) nyata dapat meningkatkan bobot buah $\operatorname{tanaman}^{-1}$ yaitu berturut-turut $17.5 \%$ dan $24.4 \%$ maupun bobot buah $\mathrm{ha}^{-1}$ yaitu $21.2 \%$ dan $24.8 \%$, sedangkan pada pengurangan pupuk sintetik menunjukkan bahwa pengurangan dosis $25 \%$ tidak berbeda nyata dengan dosis pupuk rekomendasi terhadap bobot buah $\operatorname{tanaman}^{-1}$. Pada kombinasi perlakuan pupuk mikotricho dan pengurangan dosis pupuk sintetik (Tabel 1), pemberian pupuk mikotricho dosis $20 \mathrm{~g}$ (10 g mikoriza + $10 \mathrm{~g}$ Trichoderma) maupun $40 \mathrm{~g}(20 \mathrm{~g}$ mikoriza $+20 \mathrm{~g}$ Trichoderma) dengan dosis rekomendasi pupuk sintetik tidak akan direkomendasikan karena tujuan penelitian ini adalah untuk mengurangi pemakaian pupuk sintetik tersebut dengan mengaplikasikan pupuk mikotricho yang ramah terhadap lingkungan. Dalam pemberian pupuk mikotricho dosis $20 \mathrm{~g}$ (10 g mikoriza $+10 \mathrm{~g}$ Trichoderma) maupun $40 \mathrm{~g}$ (20 g mikoriza + 20 g Trichoderma) dengan pengurangan dosis pupuk sintetik 25\% menunjukkan pengaruh yang sama secara nyata. Namun, dipilih dosis pupuk mikotricho $40 \mathrm{~g}$ ( $20 \mathrm{~g}$ mikoriza $+20 \mathrm{~g}$ Trichoderma) berdasarkan peningkatan bobot buah cabai yang nyata. Pada dosis $40 \mathrm{~g}$ (20 g mikoriza $+20 \mathrm{~g}$ Trichoderma) dengan pengurangan dosis pupuk sintetik 25\%, peningkatan hasil buah tanaman ${ }^{-1}$ nyata sebesar $23.9 \%$ dan $22.2 \%$ pada hasil $\mathrm{ha}^{-1}$ dibandingkan tanpa pupuk mikotricho dan dosis rekomendasi pupuk sintetik, sedangkan pada dosis $20 \mathrm{~g}(10 \mathrm{~g}$ mikoriza $+10 \mathrm{~g}$ Trichoderma) dengan pengurangan dosis pupuk sintetik $25 \%$ nyata terjadi peningkatan bobot buah tanaman ${ }^{-1}$ sebesar $14.7 \%$ dan $15.8 \%$ dibandingkan tanpa pupuk mikotricho dan dosis rekomendasi pupuk sintetik. Pemberian pupuk mikotricho dosis $40 \mathrm{~g}$ (20 g 
mikoriza +20 g Trichoderma) maupun $20 \mathrm{~g}$ $(10 \mathrm{~g}$ mikoriza $+10 \mathrm{~g}$ Trichoderma $)$ meningkatkan hasil diduga akibat persentase infeksi mikoriza pada akar tanaman yang nyata lebih tinggi dibandingkan kontrolnya (tanpa pupuk mikotricho). Kombinasi yang dipilih adalah kombinasi perlakuan dengan peningkatan hasil yang nyata lebih tinggi pada hasil cabai tersebut yaitu pada pupuk mikoriza $20 \mathrm{~g}+$ Trichoderma $20 \mathrm{~g}$ dan pengurangan dosis pupuk sintetik 25\% dari rekomendasi. Hal ini sejalan dengan pengaruh mikotricho terhadap pertumbuhan jumlah dan luas daun serta jumlah cabang tanaman.Peran mikoriza dan Trichoderma yang membantu dalam penyediaan unsur hara sehingga dapat mengurangi pupuk sintetik dan mempengaruhi pertumbuhan tanaman yang akhirnya mempengaruhi hasil buah cabai. Pengurangan dosis pupuk sintetik (Urea, ZA, SP27 dan $\mathrm{KCl}$ ) sebanyak $25 \%$ dari dosis rekomendasi menunjukkan sudah tercukupinya unsur hara karena adanya peran mikoriza dan Trichoderma yang membantu dalam menyediakan unsur-unsur hara yang dibutuhkan tanaman cabai serta hormon yang dihasilkan. Menurut Marwani et al. (2013), semakin banyak spora mikoriza yang diaplikasikan pada akar tanaman semakin tinggi pula tingkat infeksi dan kolonisasi mikoriza yang terjadi. Namun perlu diingat bahwa penambahan tersebut mempunyai titik optimum, karena dengan bertambahnya dosis mikoriza yang diberikan akan terjadi persaingan yang terjadi antara cendawan tersebut dalam mendapatkan makanan yang berupa fotosintat dalam tubuh tanaman inangnya. Menurut Musfal (2010) pada pemberian mikoriza $(\mathrm{CMA}=$ cendawan mikoriza arbuskula) dosis tinggi diduga berkaitan dengan kompetisi CMA itu sendiri dalam menginfeksi akar.

Pemakaian dosis pupuk yang optimum sangat penting, karena dosis rendah menjadi kurang bermakna sedangkan dosis terlalu tinggi menjadi tidak efisien. Menurut Saleh et al. (2017), peningkatan dosis mikoriza (CMA) dari dosis optimum akan menurunkan potensi hasil, karena CMA dalam bersimbiosis dengan tanaman juga membutuhkan karbohidrat yang diperoleh dari akar tanaman.

\section{KESIMPULAN}

Pemberian pupuk hayati mikotricho hingga $40 \mathrm{~g}(20 \mathrm{~g}$ mikoriza $+20 \mathrm{~g}$ Trichoderma) tanaman ${ }^{-1}$ dapat meningkatkan pertumbuhan dan hasil cabai merah. Pengurangan dosis pupuk sintetik yang berupa urea, ZA, SP27 dan $\mathrm{KCl}$ hingga 25\% dari dosis rekomendasi menunjukkan pertumbuhan dan hasil cabai merah yang lebih baik dibandingkan dengan pemberian dosis rekomendasi pupuk sintetik. Pemberian pupuk mikotricho dosis $40 \mathrm{~g}$ (20 g mikoriza $+20 \mathrm{~g}$ Trichoderma) dengan pengurangan $25 \%$ pupuk sintetik dari dosis anjuran memberikan pertumbuhan jumlah daun, luas daun, dan jumlah cabang serta peningkatan hasil cabai $\left(15.4 \mathrm{t} \mathrm{ha}^{-1}\right)$ sebesar $22.2 \%$ dibandingkan tanpa pupuk mikotricho dengan dosis rekomendasi pupuk sintetik $\left(12.6 \mathrm{t} \mathrm{ha}^{-1}\right)$. Sedangkan pada dosis pupuk mikotricho $20 \mathrm{~g}$ (10 g mikoriza + $10 \mathrm{~g}$ Trichoderma) dan pengurangan dosis pupuk sintetik $25 \%$ peningkatan hasil buah $\mathrm{ha}^{-1} 15.8 \%\left(14.6 \mathrm{t} \mathrm{ha}^{-1}\right)$ dibandingkan tanpa pupuk mikotricho dan dosis rekomendasi pupuk sintetik.

\section{DAFTAR PUSTAKA}

Baskoro, D., B.S. Purwoko. 2010. Pengaruh bahan perbanyakan tanaman dan jenis pupuk organik terhadap pertumbuhan tanaman binahong (Anredera cordifolia (Ten.) Steenis). J. Hort. Indonesia. 2(1): 6-13.

Charisma, A.M., Y.S. Rahayu, Isnawati. 2012. Pengaruh kombinasi kompos Trichoderma dan mikoriza vesikular arbuskular (MVA) terhadap pertumbuhan tanaman kedelai (Glycine max (L.) Merill) pada media tanam tanah kapur. Lentera Bio. 1(3): 111116.

Cruz, C., J.J. Green, C.A. Watson, F. Wilson, M.A. Martin. 2004. Functional aspect of root architecture and mycorrhizal inoculation with respect to nutrient uptake Capacity. Mycorrhiza. 14: 177184. 
Dwiastuti, M.E., M.N. Fajri, Yunimar. 2015. Potensi Trichoderma spp. sebagai agens pengendali Fusarium spp. penyebab penyakit layu pada tanaman stroberi (Fragaria x ananassa Dutch.). J. Hort. 25(4): 331-339.

Faranso, D., A.D. Susila. 2015. Rekomendasi pemupukan fosfor pada budidaya caisin (Brassica rapaL. cv. caisin) di tanah andosol. J. Hort. Indonesia. 6(3): 135143.

Harpenas, A., R. Dermawan. 2011. Budidaya Cabai Unggul. Penebar Swadaya. Jakarta.

Marwani, E., P. Suryatmana, I.W. Kerana, D.L. Puspanikan, M.R. Setiawati, R. Manurung. 2013. Peran mikoriza vesikular arbuskular dalam penyerapan nutrien, pertumbuhan, dan kadar minyak jarak (Jatropha curcas L.). Bionatura. 15(1): 1-7.

Musfal. 2010. Potensi cendawan mikoriza arbuskula untuk meningkatkan hasil tanaman jagung. J. Litbang Pertanian. 29(4): 154-158.

Naemah, D., S.M. Widyastuti, Sumardi. 2003. Pengaruh Trichoderma terhadap perkembangan mikoriza pada akar Pinus merkusii Jungh. et de Vriese. Agrosains. 16(2): 173-183.

Nurhalimah, S., S. Nurhatika, A. Muhibuddin. 2014. Eksplorasi mikoriza vesikular arbuskular (MVA) indigenous pada tanah regosol di Pamekasan, Madura. J. Sains dan Seni Pomits. 3(1): 2337-3520.

Ozbay, N., S.E. Newman, W.M. Brown. 2005. The effect of the Trichoderma harzianum strains. On the growth of tomato seedling evaluation of microbial methods as potential indicators of soil quality in historical agricultural fields. Biol. Fertil. Soil. 19: 297-302.
Pangaribuan, D.H., Y.C. Ginting, L.P. Saputra, H. Fitri. 2017. Aplikasi pupuk organik cair dan pupuk anorganik terhadap pertumbuhan, produksi, dan kualitas pascapanen jagung manis (Zea mays var. saccharata Sturt.). J. Hort. Indonesia. 8(1): 59-67.

Poulton, J.L., R.T. Koide, A.G. Stephenson. 2011. Effects of Trichoderma infection and soil phosphorus availability on invitro and in-vivo pollen performance in Lycopersicon esculentum (Solanaceae). American J. Botany. 88: 1786-1793.

Prasetyo, B.H., D.A Suriadikarta. 2006. Karakteristik, potensi, dan teknologi pengelolaan tanah ultisol untuk pengembangan pertanian lahan kering di Indonesia. J. Litbang Pertanian. 25(2): 39-47.

Rokhminarsi, E., Begananda, D.S. Utami. 2011. Identifikasi mikoriza spesifik lokasi lahan marjinal sebagai pupuk hayati dalam mewujudkan pertanian berkelanjutan. Agritrop. 10(1): 12-19.

Saleh, I., I.S.W. Atmaja. 2017. Efektivitas inokulasi cendawan mikoriza arbuskula (CMA) terhadap produksi bawang merah dengan teknik pengairan berbeda. J. Hort. Indonesia. 8(2): 120127.

Sari, N., A. Fatchiya, P. Tjitropranoto. 2016. Tingkat penerapan pengendalian hama terpadu (PHT) sayuran di Kenagarian Koto Tinggi, Kabupaten Agam, Sumatera Barat. J. Penyuluhan. 12(1): 15-30.

Sukmawaty, E., Hafsan, Asriani. 2016. Identifikasi Cendawan Mikoriza Arbuskula dari Perakaran Tanaman Pertanian.Biogenesis. 4(1): 16-20.

Suwardi, H. Wijaya. 2013. Peningkatan produksi tanaman pangan dengan bahan aktif asam humat dengan zeolit sebagai pembawa. J. Ilmu Pertanian Indonesia. 18(2): 79-84. 